\title{
Localism and the Design of Political Systems
}

\section{Rick Harmes}

First published in 2021

\section{Localism and political systems in the twenty-first century}

(CC BY-NC-ND 4.0)

This OA chapter is self-funded by the author, Rick Harmes

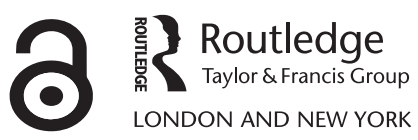




\section{Localism and political systems in the twenty-first century}

This final chapter focuses on the design of political institutions and systems. Not only is design thinking a key element of an engaged political analysis (Stoker, 2013), but it is also particularly relevant at the present time, as countries struggle with the Covid-19 pandemic which has engulfed the world during 2020. This unprecedented public health crisis has forced governments to take a series of exceptional steps, severely curtailing normal life and commerce in order to protect the lives of citizens. The widespread restrictions that have been imposed may take years to unwind fully, and the pandemic's longer-term impacts will affect many public functions, regardless of whether they are carried out by government, commerce or civil society. There is already much speculation about how the institutions and processes that shape our everyday lives will be transformed in the light of the crisis. Will the crisis have the same long-term impact on society and politics as the two World Wars did in the twentieth century? Are we at a historical turning point where political systems are set for a quickening in the pace of reform and redesign?

In this chapter, I begin by restating the main arguments across the whole of the book so far. I then go on to consider some of the main elements of the twentyfirst-century design context, particularly the pre-Covid impacts of globalization and economic development, as well as the counter-trend in authoritarian populism which is now rampant in many parts of the world. At this point I also consider some current trends in multi-level governance (MLG), as this is where any redesign of systems is likely to be focused in future. This leads to the chapter's main section on localism and the design of political systems. Here, I set out several ideas for systemic political reform, as well as some thoughts about how political design activity is likely to become more institutionalized in the years to come. The chapter concludes with some key statements about localism and the design of political systems.

\section{The argument so far}

\section{Chapter 2}

The term 'localism' denotes a clear valorization of the local dimension in politics and is often counter-posed to the power of the state and/or the impact of 
globalization. Localism can be understood in both a core and a secondary sense, depending on the scale of the events being described. Core localism focuses on activity at the micro scale of social and political organization. Secondary localism denotes activity at the meso scale, immediately below the level of the sovereign state. The best framework for analysing localism is that provided by MLG. Localist activity and discourse may flow from one of three power dynamics: top-down, bottom-up or collaborative. In real-world situations, two or more of these dynamics may be present alongside each other. For the purposes of political analysis, it is the mix between them that matters (Evans et al., 2013: 614).

\section{Chapter 3}

Place, space and scale are fundamental elements of social and political organization. But while place and space are important, it is ultimately scale which is the decisive factor in power relationships (Swyngedouw, 1997: 145). Most communities of place, at whatever scale they are constituted, have a specific identity, as well as an element of social structure and political governance. These elements are formed through sociological processes of 'structuration', and they may result in 'scalar fixes' of varying temporal durations (Brenner, 2001: 604-609). Over the course of history, scalar structuration processes have become increasingly sophisticated. In recent times, they have resulted in the emergence of sovereign states as the default mechanism for co-ordinating affairs within the public realm. In the early stages of state formation, the principal dynamic was towards integration and assimilation. After 1950 this pattern began to change, and many states began to decentralize certain policy functions (Bohlken, 2016; Hooghe and Marks, 2016).

At the same time, there has been a significant growth in international relations activity involving sovereign states, as well as a notable growth in the number of small states operating independently within the international system (Alesina and Spolaore, 2003). In addition, many key aspects of finance, trade, economics and culture have moved beyond the ambit of states altogether and have become part of globalized networks of relationships. This has resulted in many smaller and medium-sized states choosing to align themselves with georegional power blocks, where the economic interests of their citizens can be better served within a globalizing world. The most prominent of these blocks is the European Union (EU). This formidable institution, which has been likened to a modern-day empire (Zielonka, 2006), has been at the forefront of developing a flexible style of MLG, where policies and measures are built on the inputs of multiple actors, geographical hubs and scalar levels (Piattoni, 2010). The unique modus operandi of the EU has gone some way towards promoting the idea of regional and sub-national autonomy within a wider sub-continental system of governance. However, the EU has been powerless to intervene effectively in the fraught stand-off over territorial sovereignty currently playing out between Catalonia and Spain. 


\section{Chapter 4}

The contrast between 'old' and 'new' localism is explored, particularly within the context of the UK. 'Old' localism is principally about established local governance, which in certain parts of the world has a long and distinguished history. At the same time, the establishment of local governance structures in developing countries continues to be a major focus of international bodies such as the International Monetary Fund and the World Bank (Shah and Shah, 2006). Theories about the role of established local governance have emphasized either its contribution to a wider system of national government or its role as a vehicle for the expression of local identity (Pratchett, 2004). In some countries, there are well-developed systems of neighbourhood governance, and this has led to an increasing amount of academic and policy interest in the issue of governance at the micro level (Lowndes and Sullivan, 2008). The primacy of locality governance has received critical support from Green political theory and from citizen initiatives built on digital technologies, such as the Transition Network (Hopkins, 2011). Such initiatives are aimed at challenging the conventional discourse of neighbourhoods as rural backwaters of parochialism and ignorance (Tomaney, 2012), or as post-industrial wastelands where communities find themselves left behind by the impacts of globalization.

The fact is that digital technologies have brought about a significant transformation in the position of local communities vis-à-vis elites and established power geometries (Sassen, 2006). They allow localities to bypass existing power hierarchies and to connect with each other across physical space, thus enabling them to exercise a much greater 'localist' influence on world affairs. For example, city mayors are now convening annually to meet within their own Global Parliament (Barber, 2013). The shifting nature of contemporary localism within an MLG system is reflected powerfully in the case study of the Cornwall/Isles of Scilly subregion. Although conscious of its distinctive identity and of its desire to be an autonomous political player, Cornwall is somewhat constrained by having to operate within the UK's top-down governance culture (Blunkett and Richards, 2011).

\section{Chapter 5}

Public value (PV) is a fundamental element in the design of political institutions and systems (Benington and Moore, 2011). The chapter argues that PV should be understood in the broadest possible sense as encompassing all aspects of good and effective governance. PV indicates a set of outcomes, or a state of affairs, resulting from previous social and political action and policy making. It should be seen as the goal of all governmental strategy. Two fundamental pillars of public value are political order and political development (Fukuyama, 2011, 2015), but we should also be aware that, if good and effective governance is systematically undermined, states can also end up sliding into political decay (Fukuyama, 2015: 455-548). The chapter discusses three major domains of public value, which are 
applicable to some degree across all polities. These are democracy and accountability, human wellbeing and environmental sustainability. The chapter discusses how localism intersects with each of these domains. Of the three, democracy and accountability is the one with the longest historical pedigree, whereas environmental sustainability is the one that has emerged most recently. Environmental sustainability is also essentially about whole ecological systems, rather than about individual institutions or specific territorial units.

In policy terms, these three major domains of public value are increasingly being addressed in a joined-up way, and this is particularly evident in the broad scope of the 17 Sustainable Development Goals adopted by the UN in September 2015 (Sachs, 2015). In addition to the three major domains just highlighted, the chapter discusses a further, system-based, domain of public value: territorial cohesion (TC). It shows how TC is being addressed within the context of the EU. The advantage of TC is that it cuts across individual sectors and encourages an integrated and strategic approach to policy. This in turn encompasses economic effectiveness, social cohesion and ecological balance. It puts the sustainable development of individual places at the heart of policy making and institutional action (CEC, 2008). It can be seen as an attempt to promote a kind of 'spatial justice' across the diverse territorial communities of the EU.

\section{Chapter 6}

This looks specifically at the design of political institutions and systems. Political institutions can emerge naturally, or they can be intentionally designed to achieve specific purposes. However, not all political designs turn out as their sponsors intended (Goodin, 1996). Political design is as much about the 'software' of competing political discourses, as it is about institutional 'hardware' of structures and procedures. There is likely to be much more scope for political redesign in circumstances which are volatile or indeterminate, and where the 'realist constraints' which normally make reform difficult are less in evidence (Dryzek, 1996). This is because of the phenomenon of 'path dependence', which tends to make institutional structures self-reinforcing over time and to inhibit the scope for major reform (Pierson, 2000). In these circumstances, only small-scale reform or institutional 'bricolage' is possible. In fact, political reformers must accept the fact that they will generally fail to meet their objectives (Lowndes and Roberts, 2013). Political design may be carried out at different levels: at that of individual institutions; or at that of a whole polity; or even, in principle at least, at the level of an entire, sub-continental political system. The more extensive the canvas, the more important it is for political design to be based on an appropriately broad set of principles.

The chapter sets out seven design principles for effective political governance at the continental/sub-continental scale. The principles have been formulated with localism and public value specifically in mind, and they represent a particular normative stance. The seven principles concerned are (1) rootedness; 
(2) environmental awareness; (3) human wellbeing; (4) citizenship; (5) mutuality and territorial cohesion; (6) sustainability and resilience; and (7) learning and public value. With regard to current design trends, while many states have been moving towards a more decentralized pattern of territorial governance over the past 70 years (Hooghe and Marks, 2016), there are as yet few examples of states that have been designed with micro-level governance in mind. One notable exception is India, whose major constitutional reforms of 1993 established a third tier of federal governance at the village and urban-ward level. These groundbreaking Indian reforms were inspired by the visionary localism of early twentieth-century political reformer Mahatma Gandhi (Chakrabarty, 2017).

\section{Chapter 7}

This chapter discusses how public value outcomes can be evaluated at the local level. In order to facilitate this task, the chapter sets out a local outcomes framework based on seven key aspects, including (1) local identity; (2) local prosperity and flourishing; (3) civil society and governance at the community level; (4) links with the wider world; (5) autonomy and upward influence; (6) constitutional recognition; and (7) mutuality and cohesion. The first five of these aspects are intended to capture features which are inherently local in nature. The remaining two refer to system-level features which are believed to be essential in enabling an effective approach to localism within a multi-level context. The framework is used to present an illustrative assessment of recent localism policy in the Cornwall/ Isles of Scilly sub-region in south-west England. The framework was inspired by the Comprehensive Area Assessment, which was developed by the UK's former Audit Commission, and used in England for one year only in 2009-2010.

\section{The book's main questions}

With regard to the three questions set out in the book's opening chapter, the first of them ('What is localism about and what does it involve?') is addressed principally by the conceptual and analytical arguments set out in Chapter 2. The second ('How useful and important a concept is localism?') is addressed in Chapters 3, 4 and 5. The final research question ('How can localism make a meaningful contribution to the task of institutional and system design?') has already been addressed through the arguments set out in Chapters 6 and 7. I will now complete my analysis of that question in the remaining part of this chapter.

\section{The twenty-first-century design context}

According to Stephen Pinker (2019: 81), there has been a hundredfold increase in gross world product since the time of the Industrial Revolution. As a result, many parts of the world have experienced a 'Great Escape' from poverty. In recent years, the Great Escape has been followed by a 'Great Convergence', as many 
more countries have become rich in their turn. For example, by 2008 the world's population (6.7 billion at the time) had an average income equivalent to that of Western Europe in the 1960s, and throughout the whole of this period extreme poverty has continued to decline. According to Pinker, globalization has turned out to be a 'bonanza for the poor' (Pinker, op. cit.: 92). Although there has been a rise in financial inequality in the wealthier nations since 1980, this has been more than offset by the overall decline in inequality worldwide. The relative 'losers' of globalization have therefore been lower-middle-class citizens in better-off countries. That said, even these 'losers' have continued to see modest increases in their standard of living during this period, and there has also been a gradual reduction in absolute poverty at the bottom of the income distribution (Pinker, op. cit.: 118).

In response to these developments, there have been two major backlashes against globalization over the past 20 years. On the one hand, there has been the rise in anti-establishment radicalism and the threat of protest, and even terrorism, which arises from it. On the other - and partly to counter to the challenge of antiestablishment radicalism - there has been a rise in authoritarian populism of the nationalist Right. The latter can be seen in the emergence of 'strongmen' leaders in a number of countries across the world, including Putin in Russia, Erdogan in Turkey, Orban in Hungary, Modi in India (see Chapter 6), Duterte in the Philippines, Bolsonaro in Brazil and Trump in the United States. These leaders and their programmes represent a pushback of tribalism and authoritarianism against the Enlightenment values that have driven political development across the world, particularly since the end of the Second World War (Pinker, op. cit.: 333). According to Pinker, those who support Donald Trump and other authoritarian leaders are the losers, not so much of economic competition as of competition in the cultural sphere.

What now seems to be emerging internationally are two broad groupings of states: on the one hand, there is a group of mainly small and medium-sized states, but including the EU as well, that remain broadly committed to a world order based on good governance and on public value principles; on the other, there is a group of mainly larger countries that have swung towards a much more 'heroic' view of the sovereign state. These nations, and many others within their ambit, are bent on projecting their economic and military power, and are reluctant to be bound by international law and institutions except where it suits them. The number of countries belonging in each of these camps is in regular flux, and much depends on which regime is in power in a state at any one time: for example, the United States under the leadership of Donald Trump, as opposed to the same country under Barack Obama. The British government's recent decision to leave the EU represents an unmistakeable bid to join the latter group of states. In the light of the most recent events, however, a key uncertainty is what impact the Covid-19 pandemic will have on the emerging international order as it has been briefly sketched out here. In the light of the common threat now facing the world, will there be more co-operation and shared action between the world's sovereign states in future, or less? 
One of the effects of political regimes led by nationalist 'strongmen' is to concentrate power at the political centre and to diminish the influence of state legislatures and territorial governments, including in countries where governance at the sub-national level is already well developed, as, for example, in the United States, Brazil and India. But even in states where the political style of the regime is less polarizing, there can be tensions between the political centre and the state's sub-national territories. This may explain why the long-term global trend towards decentralization has slowed perceptibly in recent years (Hooghe and Marks, 2016: 52 ), and why the creation of new sovereign states, particularly smaller ones, has also stalled since the millennium (Corbett and Veenendaal, 2019). The question is whether these trends will eventually resume in the same direction as before, or whether they will go into reverse at some point.

On the other hand, there are massive global pressures for greater resilience to be developed at the level of regions and localities (Sovakool and Brown, 2009; Bulkeley, 2011). Many of these pressures arise from the urgent ecological challenges which the world is facing (Sachs, 2015; see also Chapter 5). The ecological case for greater localism seems to be supported by the international experience in dealing with the Coronavirus pandemic so far. The states that have been most effective in stopping the initial spread of the disease, such as New Zealand, South Korea and Germany, have been able to achieve this by following World Health Organization guidelines and focusing on mass local testing, follow-up contact tracing, and support for vulnerable individuals within their communities. ${ }^{1}$ In the absence of an approved and widely available vaccine for the virus, sustained local health interventions are likely to be the only effective way in which the effects of the pandemic can be kept at bay. All this helps to build the normative case for a more local dimension to be built into political design at the global level.

\section{Designing political systems}

In addressing the issue of political design, there are three distinct aspects to address. These are set out next under the following sub-headings: core issues; key areas of system design; and options, structures and prospects.

\section{Core issues}

As noted in Chapter 2, 'design' is an Enlightenment concept which valorizes the importance of rational thinking about ends and means (Goodin, 1996). This raises an important question about the philosophy of political design, and about the type of normative commitment it represents. In recent years, a comprehensive rationale for rational political design has been provided by Stephen Pinker in his book Enlightenment Now. ${ }^{2}$ For Pinker, the term 'enlightenment' ties together four major themes: reason, science, humanism and progress (Pinker, 2019: 8). Pinker notes that in the eighteenth century, Enlightenment hopes for progress were very much focused on the development of institutions. Human-inspired constructs such as 
governments, laws, places of learning, markets and international organizations were all seen as being suitable objects for the application of reason in the pursuit of human betterment. One of the most famous documents of the Enlightenment period, the American Declaration of Independence, proclaimed that governments are established in order to ensure that individuals enjoy the right to life, liberty and the pursuit of happiness, and also that governments derive their powers from the consent of the governed (Pinker, op. cit.: 12). This sentiment not only reflects an Enlightenment point of view but also forms the basis for today's public value ethic.

As emphasized throughout this book, contemporary political design has to take into account the complexities of MLG. In this context, one of the core challenges of many design briefs is to deal convincingly with the challenge of 'articulation' between the different layers of governance within an MLG system (Cvetkovic and Kellner, 1997). This is particularly so, the broader the design context happens to be. As we saw in Chapter 5, for example, Paul Hirst sets out a compelling case for voluntary-sector associations to take over the responsibility for local welfare provision from public sector institutions (Hirst, 1994). Yet Hirst never really explains how his proposed pattern of 'associationalist' welfare providers will interface with the wider structures of public power which also form an essential part of his vision. Similarly, the main weakness of Mahatma Gandhi's vision of village republics within the new, independent state of India is that it pays no attention at all to how reformed village governance bodies will interface, either with large centres of population situated nearby or with the national state apparatus (Gandhi, 1941). Fortunately for us, India's modern state of Kerala is able to offer a world-leading example of how ultra-localism at the neighbourhood level can be articulated effectively with the public policy priorities of a highly populated sub-national state. With its Kudumbashree mission, in particular, Kerala has succeeded in translating Gandhi's utopian vision of local neighbourhood governance into practical organizational fact (see Chapter 6).

This in turn raises questions about the overall power dynamic which lies behind political design in general. Should it be seen as a blueprint to be imposed from the top-down, or does it represent a radical break with the past to be inspired from the bottom-up? Or should it instead seek to balance a number of diverse and conflicting approaches? Given this book's defining focus on localism, there are many reasons why it might be tempting to come down in favour of a bottom-up approach to political design. However, the wider explanatory power of MLG has also been acknowledged throughout the book. In my view this is the perspective which ultimately has to be the decisive one. The approach to political design favoured here, therefore, is the 'balanced diversity' approach. This would seem to be especially well suited to addressing the broader design requirements of subcontinental political systems.

\section{Key areas of system design - some proposals}

What follows is a brief outline of some specific areas of political design, which might be developed within political and territorial systems in future. All the areas 
discussed next have one thing in common: they have a distinct element of place and/or localism associated with them.

A low-profile starting point would be the establishment of an official register of all 'recognized places' located within a particular jurisdiction. This would be a detailed database of all relevant places, no matter how local or insignificant they may appear to be. To qualify for inclusion in the register, a place would not necessarily require an element of formal political governance. Nor would it need to have any built or human element to it; it might be an uninhabited area such as a forest or a moor. Reform along these lines would allow individual polities and political systems to develop a detailed geographical profile of all the places which make up the territory for which they are responsible - in effect, a sort of modern Domesday Book. ${ }^{3}$ This could be a useful resource for supporting the ecological management of the territory and for addressing wider cohesion policy. In due course, such a database could also provide the basis for extending place-based rights, entitlements and representation (see later).

A second area of reform would involve the establishment of a system of Universal Basic Services (UBS) for all individuals and local communities within the relevant jurisdiction (Gough, 2019; see also Chapter 5). This could include a Universal Basic Income for adult citizens financed out of taxation (van Parijs and Vanderborght, 2017), and perhaps supplemented from philanthropic donations. As Gough concedes, this approach would involve much greater government intervention in the foundational economy than exists at present. A system of UBS would ensure that all citizens were entitled to access the services officially deemed to be essential for supporting everyday life, including nutrition, accommodation, transport and information technology. Not all the services specified within the UBS spectrum would necessarily be offered free of charge at the point of delivery, and by no means all of them would be provided by public agencies. The task of striking the right balance between different types of providers would fall to the relevant local, regional and national authorities. The system would need to reflect wider social norms and attitudes and be shaped by public debate and discussion. Under a UBS system, the precise balance of designated services would need to be regularly reviewed and all major changes should be confirmed through a process of democratic decision-making.

A third area of systemic reform involves an extension to the way in which individual democratic rights are conceived, particularly the right to political representation. At present, such rights are focused predominantly on the individual citizen. This leads to a mindset in which rights are generally seen as applying to individuals alone. Thinking about rights in this rather atomized way can undermine the notion of democratic rights in general and can risk leaving individual citizens exposed if they have to defend their rights against an overmighty state or bureaucracy. The weakness of this 'methodological individualism' has been identified previously by a number of eminent scholars, including Michael Sandel (1982) and Iris Marion Young (1986). This book has made a strong case for the extension of collective democratic rights to a whole range of entities, including localities of all sizes. As argued in Chapter 5, democracy and accountability for 
individual citizens are immeasurably strengthened when they are aligned with the collective dimension of democracy for localities and communities.

In implementing rights reform along these collective lines, a number of different factors need to be taken into account. Localities and neighbourhoods would need to be officially defined for the purpose of being able to exercise their placebased rights. This is where the formal register of recognized places proposed earlier could play a critical role. And the constitutional rights and powers of places would also need to be formally set out in legislation. Finally, the rights of formal representation of all local governance bodies would need to become an accepted part of local, regional, national and international governance. For example, the powers of the EU's Committee of the Regions (see Chapter 5), which was considered to be a significant institutional innovation when it was first created in 1994, might now be extended so as to more closely match those of the European Parliament. Perhaps the Committee's remit might even be extended so that in future it becomes a Committee of the Regions and Localities? Or maybe it could morph into a new and equally influential Committee of European Mayors?

This last area of reform could be part of a much more thoroughgoing effort aimed at establishing localism as a formal constitutional principle, similar to that of equal rights, for example. Accordingly, the local dimension would become a key factor in all policy making and evaluation. This is where something like the localism framework presented in Chapter 7 could have a useful role to play. All relevant state policies could be evaluated to establish how effective they are in improving local outcomes across a range of key public value domains.

New constitutional rights for regions/sub-regions and localities could also be framed so as to enable them to form transnational partnerships with other similar entities internationally, provided that such links have the support of local citizens. As noted in Chapters 4 and 5, trans-local activity of this kind is already well established in many parts of the world today. One current example is the EU's Groupings on Territorial Cooperation (EGTCs), which were described in Chapter 5 (Holder and Layard, 2011). Many of these groupings are cross-border initiatives involving government, private and civil society partners, and their role is to address key issues of common territorial concern, particularly where these cross international borders. I have drawn attention to the increasing profile of international groupings such as the C40 Cities and the Global Parliament of Mayors, both referred to in Chapter 4. This increasingly fluid pattern of cross-border activity on the part of cities, regions and localities is now a key element in the contemporary political landscape, and it should certainly be a part of macro-level thinking about optimal system design.

\section{Options, structures and prospects}

Today, political and institutional design activity is already well established across the world, especially through the international development activities of organizations such as the World Bank or Development Alternatives 
Incorporated (usually known by its short title, DAI). Obviously, there is a specific and well-understood rationale for the international development work that these organizations are involved in. Nevertheless, it is noticeable just how much activity in this field - both past and present - involves the design and implementation of decentralized governance programmes in developing countries, as highlighted in Chapters 4 and 6. For example, the comprehensive local self-government reforms that took place in India in the early 1990s were very much influenced by the World Bank and its two major development reports of 1989 and 1992 respectively (Chakrabarty, 2017: 52). Decentralization of both governance and economic activity continues to be a major theme within international development. This can be seen in the work that DAI is currently engaged in to support the establishment of a new regional tier of government in Morocco (DAI, 2020).

The international development aspect of political design is a well-established part of the current scene and it will no doubt continue to flourish in years to come. There are, however, other models for organizing and institutionalizing political design activity. It could conceivably be delivered by academic institutions, or by private consultancy, or even by government itself. Or it could be delivered through some hybrid arrangement that encompasses more than one of these organizational types.

As far as academia is concerned, Gerry Stoker (2010: S80) conceded some years ago that the political science profession lacks a 'design arm' and that it really needs to develop one if the discipline is going to be seen as relevant by politicians and policy makers. That point notwithstanding, some of the most highly respected institutional design work to emerge from the academic sector in the past 50 years is that which developed from the 1970s onwards under Elinor and Vincent Ostrom and their Bloomington School collaborators at the University of Indiana (Aligica and Tarko, 2012). In particular, Elinor Ostrom went on to develop a worldwide reputation for her work on polycentric systems and the collaborative governance of the commons (Ostrom, 1990), culminating in her receiving the Nobel Prize for Economics in 2009. ${ }^{4}$ The Ostroms' highly influential work in this area shows that there is scope for the higher education sector to develop considerable expertise within the 'applied' sub-discipline of political design, provided there is suitable investment in research and consultancy capability.

Of the three organizational options listed earlier, private consultancy is perhaps the most flexible, but it will often be unable to provide the institutional mass needed for large-scale projects. By contrast, a government agency specializing in design is likely to have a degree of credibility in the field and a reasonable level of institutional capacity to go with it. However, it may also be inflexible in its approach and quite liable to be influenced by a range of political pressures. In contrast to these two models, a university setting is likely to have both the requisite capacity and an internal culture geared to producing high-quality, independent research. Higher Education research operations are also routinely carried out in collaboration with other academic institutions worldwide, and they 
may even be able to attract the support of enlightened government partners, for example the EU.

A university research institute of the kind envisaged here could address any number of research and development priorities within the field of political design. These might include some of the critical issues that have been raised in the pages of this book, for example further studies into articulation within MLG systems; place-based public policy; ultra-localism, including Kerala's Kudumbashree mission; and the detailed development of a Localism Index for quantifying the effectiveness public policy outcomes in localities (see Chapter 7). A research agenda of this type is likely to provide plenty of challenging material for an engaged political science to address. It is certainly possible to look forward to a time when the multi-level design of political systems will become both more institutionalized and more mainstream at the same time.

\section{In conclusion: ten propositions}

1 Localism is a perspective which places a special value on the local dimension of social organization and politics. In politics, localism should be seen as part of a broader pattern of multi-level governance.

2 As a perspective, localism can be used to analyse political events at both the neighbourhood level (core localism, or 'real' localism) and the level of regional/sub-national government (secondary localism).

3 Localism is one of several perspectives which explore how the geographical notions of place, space and scale are currently being reimagined globally.

4 These perspectives are shining a new light on our accepted notions of the sovereign state. Over the past 70 years there has been a tripling in the number of states across the world, many of which are either small or very small.

5 Over the same period there has been a burgeoning of public policy activity within states and a steady growth in decentralization in most of the larger ones.

6 Public policy activity within states has been focused on various fundamental domains of public value, including the establishment of peace and political order; the pursuit of political and economic development; the promotion of democracy and accountability; the establishment of systems to support human wellbeing; and efforts to achieve environmental sustainability and promote territorial cohesion. Public policy is becoming ever more integrated and system-focused.

7 Today, there is increasing scope for localities to act as agents in their own right. They are rapidly emerging from centuries of parochialism and lack of political power.

8 Across the world, increasing emphasis is being placed on political reform and on the redesign of political institutions and systems.

9 So far, very few states have undertaken reforms based on micro-level design. The main exception is India, which created a third constitutional tier of 
village councils and municipalities in 1993. The Indian reforms are based on the utopian vision of Indian political reformer Mahatma Gandhi.

10 If there are to be more reforms of this kind in future, political leaders must reconcile the idea of a unitary sovereignty vested in the nation state with that of autonomy at the regional and local levels. A radically different approach is needed - one where sovereignty is shared across all the constituent parts of a polity, and where local communities have a distinct role to play in the design of political systems.

\section{Notes}

1 See Gaskell and Stoker (2020) for an early analysis of the differences of approach to tackling the virus between the UK and Switzerland. Meanwhile, in India, the state of Kerala has been very successful so far in managing the effects of the pandemic (Spinney, 2020).

2 However, Pinker's book is not actually about political design as such, and the issue of design is not explicitly discussed by him.

3 Although, hopefully, a much more scholarly and benign version of the original Norman document!

4 Ostrom was the first woman to win the Economics prize. She is one of only two women laureates in the whole of the prize's 50-year history to date.

\section{References}

Alesina A and E Spolaore (2003): The Size of Nations. London: The MIT Press

Aligica P and V Tarko (2012): 'Polycentricity: From Polanyi to Ostrom, and Beyond', in Governance, Vol. 25(2), 237-262

Barber B (2013): If Mayors Ruled the World: Dysfunctional Nations, Rising Cities. London: Yale University Press

Benington J and M Moore (eds.) (2011): Public Value: Theory \& Practice. Basingstoke: Palgrave Macmillan

Blunkett D and D Richards (2011): 'Labour In and Out of Government: Political Ideas, Political Practice and the British Political Tradition', in Political Studies Review, Vol. 9(2), 178-192

Bohlken A (2016): Democratization from Above: The Logic of Local Democracy in the Developing World. New York: Cambridge University Press

Brenner N (2001): 'The Limits to Scale? Methodological Reflections on Scalar Structuration', in Progress in Human Geography, Vol. 25(4), 591-614

Bulkeley H (2011): 'Cities and Sub-national Governments', in J Dryzek, R Norgaard and D Schlosberg (eds.) The Oxford Handbook of Climate Change and Society. Oxford: Oxford University Press, 464-478

Chakrabarty B (2017): Localizing Governance in India. London: Routledge

Commission of the European Communities (CEC) (2008): Green Paper on Territorial Cohesion: Turning Diversity into Strength. SEC (2008) 2250. Brussels: CEC

Corbett J and W Veenendaal (2019): Democracy in Small States: Persisting against the Odds. Oxford: Oxford University Press

Cvetkovic A and D Kellner (1997): Articulating the Local and the Global: Globalization and Cultural Studies. Oxford: Westview Press 
Development Alternatives Incorporated (DAI) (2020): Morocco - TASHAROC. www.dai. com/our-work/projects/morocco-tasharoc (accessed 21 May 2020)

Dryzek J (1996): 'The Informal Logic of institutional Design', in R Goodin (ed.) The Theory of Institutional Design. Cambridge: Cambridge University Press, 103-125

Evans M, G Stoker and D Marsh (2013): 'In Conclusion: Localism in the Present and the Future', in Policy Studies, Vol. 34(5-6), 612-617

Fukuyama F (2011): The Origins of Political Order: Vol 1 - From Prehuman Times to the French Revolution. London: Profile Books

Fukuyama F (2015): Political Order and Political Decay: Vol 2 - From the Industrial Revolution to the Globalization of Democracy. London: Profile Books

Gandhi M (1941): 'Constructive Programme: Its Meaning and Place', reproduced in J Brown (ed.) (2008): Mahatma Gandhi: The Essential Writings. Oxford: Oxford University Press, 164-184

Gaskell J and G Stoker (2020): Centralised or Multi-level: Which Governance Systems Are Having a Good Pandemic? LSE Blogs. https://blogs.lse.ac.uk/politicsandpolicy/ governance-systems-covid19/ (accessed 21 May 2020)

Goodin R (1996): 'Institutions and their Design', in R Goodin (ed.) The Theory of Institutional Design. Cambridge: Cambridge University Press, 1-53

Gough I (2019): 'Universal Basic Services: A Theoretical and Moral Framework', in The Political Quarterly, Vol. 90(3), 534-542

Hirst P (1994): Associative Democracy. Cambridge: Polity Press

Holder J and A Layard (2011): 'Drawing out the Elements of EU Territorial Cohesion: Re-scaling EU Spatial Governance', in Yearbook of European Law, Vol. 30(1), $358-380$

Hooghe L and G Marks (2016): Community, Scale and Regional Governance: A Postfunctionalist Theory of Governance, Volume II. Oxford: Oxford University Press

Hopkins R (2011): The Transition Companion: Making Your Community More Resilient in Uncertain Times. Cambridge: Transition Books

Lowndes V and M Roberts (2013): Why Institutions Matter: The New Institutionalism in Political Science. Basingstoke: Palgrave Macmillan

Lowndes V and H Sullivan (2008): 'How Low Can You Go? Rationales and Challenges for Neighbourhood Governance', in Public Administration, Vol. 86(1), 53-74

Ostrom E (1990): Governing the Commons: The Evolution of Institutions for Collective Action. Cambridge: Cambridge University Press

Piattoni S (2010): The Theory of Multi-Level Governance: Conceptual, Empirical and Normative Challenges. Oxford Scholarship Online (accessed November 2011)

Pierson P (2000): 'The Limits of Design: Explaining Institutional Origins and Change', in Governance, Vol. 13(4), 475-499

Pinker S (2019): Enlightenment Now: The Case for Reason, Science, Humanism and Progress. London: Penguin Books

Pratchett L (2004): 'Local Autonomy, Local Democracy and the 'New Localism', in Political Studies, Vol. 52(2), 358-375

Sachs G (2015): The Age of Sustainable Development. New York: Columbia University Press

Sandel M (1982): Liberalism and the Limits of Justice. Cambridge: Cambridge University Press

Sassen S (2006): Territory, Authority, Rights: From Medieval to Global Assemblages. Oxford: Princeton University Press 
Shah A and S Shah (2006): 'The New Vision of Local Governance and the Evolving Roles of Local Governments', in A Shah (ed.) Local Governance in Developing Countries. Washington, DC: World Bank

Sovakool B and M Brown (2009): 'Scaling the Policy Response to Climate Change', in Policy and Society, Vol. 27(4), 317-328

Spinney L (2020): 'The Coronavirus Slayer! How Kerala's Rock Star Health Minister Helped Save it from Covid-19', in The Guardian, 14 May. www.theguardian.com/ world/2020/may/14/the-coronavirus-slayer-how-keralas-rock-star-health-ministerhelped-save-it-from-covid-19 (accessed 21 May 2020)

Stoker G (2010): 'Blockages on the Road to Relevance: Why has Political Science Failed to Deliver?', European Political Science, Vol. 9(1), supplement, S72-S84

Stoker G (2013): 'Designing Politics: A Neglected Justification for Political Science', in Political Studies Review, Vol. 11(2), 174-181

Swyngedouw E (1997): 'Neither Local nor Global: "Glocalization and the Politics of Scale", in K Cox (ed.) Spaces of Globalization. New York: Guilford, 137-166

Tomaney J (2012): 'Parochialism - A Defence', in Progress in Human Geography, Vol. 37(5), 658-672

Van Parijs P and Y Vanderborght (2017): Basic Income: A Radical Proposal for a Free Society and a Sane Economy. Cambridge, MA: Harvard University Press

Young I M (1986): 'The Ideal of Community and the Politics of Difference', in Social Theory and Practice, Vol. 12(1), 1-26

Zielonka J (2006): Europe as Empire: The Nature of the Enlarged European Union. Oxford: Oxford University Press 